\title{
THE SOCIAL CULTURAL EDUCATION IN THE QUR'AN PERSPECTIVE
}

\author{
Hilmi Mizani \\ Fakultas Tarbiyah dan Keguruan UIN Antasari Banjarmasin, Indonesia \\ hilmimizani.iain@gmail.com
}

Received: 23-03-2020

Revised: 19-06-2020

Accepted: 05-07-2020

\begin{abstract}
Social and cultural changes in society are increasingly challenging and demanding along with the times marked by developments in technology and communication. However, so that every challenge and change does not lead to setbacks and shapes human behavior to positive values, the value of human hedonism must be bound by positive values. This study aimed to analyze the positive values contained in the Holy Qur'an and al-Hadith. The literature review method has been used in this study to produce socio-cultural changes with thematic studies in the Koran contained in Surah QS al Hujurat: 13, Q.S.Al Qur'an S.Ar Ra'ad: 11, Q.S. Al A'raf: 34, Qur'an S. Ali Imran: 110, QS. Al A'raf: 96, QS. Al Maidah: 8, Qur'an S. Al-'Asr: 3, Q.S.Al Baqarah: 22, QS. On Tour: 21, QS. Arrum: 41, QS. Joseph: 55) and QS.Hud: 37. The conclusion of sociocultural education with thematic studies is that every change and development will be followed by other changes, but these changes lead to constructive and positive things, and the direction depends on the belief of each party. individual and collective society.

Keywords: Social Education, Culture Education, Thematic al-Qur'an and Al-Hadith
\end{abstract}

\section{Abstrak}

Perubahan sosial dan budaya dalam masyarakat semakin menantang dan menuntut seiring dengan perkembangan zaman yang ditandai oleh perkembangan teknologi dan komunikasi. Namun, agar setiap tantangan dan perubahan tidak mengarah pada kemunduran dan membentuk perilaku manusia ke nilai-nilai positif, nilai hedonisme manusia harus diikat oleh nilai-nilai positif. Penelitian ini bertujuan untuk menganalisis nilai-nilai positif yang terkandung dalam Alquran dan al-Hadits. Metode tinjauan literatur telah digunakan dalam penelitian ini untuk. menghasilkan perubahan sosialbudaya dengan studi tematik dalam Al-Quran yang terkandung dalam Surah QS al Hujurat: 13, Q.S.Al Qur'an S.Ar Ra'ad: 11, Q.S. Al A'raf: 34, Qur'an S. Ali Imran: 110, QS. Al A'raf: 96, QS. Al Maidab: 8, Qur'an S. Al-'Asr: 3, Q.S.Al Baqarab: 22, QS. Di Tur: 21, QS. Arrum: 41, QS. Joseph: 55) dan QS.Hud: 37. Kesimpulan dari pendidikan sosial-budaya dengan studi tematik adalab bahwa setiap perubahan dan perkembangan akan diikuti oleh perubaban lain, tetapi perubahan ini mengarah pada hal-hal yang konstruktif dan positif, dan arahnya tergantung pada kepercayaan masing-masing pibak. masyarakat individu dan kolektif.

Kata kunci: Pendidikan Sosial, Pendidikan Budaya, Tematik al-Qur'an dan Al-Hadits 


\section{INTRODUCTION}

Humans created by Allah, have two functions, namely as God's creatures and as social and cultural social creatures. ${ }^{1}$ Both of these functions each have a relationship between the obligation to God and fellow human beings, so that as God's creatures, humans have the obligation to obey the Creator, but as individual beings, then they are obliged to fulfill food and shelter. However, as a cultured creature, it is inseparable from the cultural symbols of society, how humans live in society and collectivity with social, religious ties and other social symbols ${ }^{2}$.

Clifford Geertz, ${ }^{3}$ as an anthropology researcher in Indonesia, is even known as an anthropologist, by examining religious culture in Javanese, Balinese society with cultural diversity. He examines how communities that coexist between Islam and Christianity but each respect each culture that exists in that society. This description tells us that socially and culturally humans cannot live alone without the help of others, and help one another and care for one another.

Culture is everything created by humans, so Piotr Sztompka, ${ }^{4}$ says culture has a history in accordance with human life. In this case, Alvin Toffler, ${ }^{5}$ divides human development through three periods. From these three periods displaying different cultures and also diverse. However, every culture that experiences development such as technology from typewriters to computers with electronic systems, ${ }^{6}$ does not change the value of the culture concerned so that cultural development that is contrary to the values of the Koran is something contrary to the nature of human value itself ? $^{\text {. }}$

Bertrand, ${ }^{8}$ noted that in the perspective of science and sociology, in fact the culture in his book Alvin L. Bertrand, understood all the perspectives of life that are owned and studied by a society and social institutions, religious beliefs, life motivation and the way values are applied to the community itself. Cultural value is something that is recognized by the community of research conducted by Aslan, ${ }^{9}$ that values are a positive legal system for

\footnotetext{
${ }^{1}$ Elly M. Setiadi dan dkk, Ilmu Sosial dan Budaya Dasar (Jakarta: Kencana, 2008), 48.

2 Aris Aryanto dkk., "Social Criticism in the Text Scripture of Dharmasonya," Komunitas: International Journal of Indonesian Society and Culture 9, no. 1 (2017): 70-80; Achmad Asrori, "Contemporary Religious Education Model on the Challenge of Indonesian Multiculturalism," JOURNAL OF INDONESLAN ISLAM 10, no. 2 (1 Desember 2016): 261-84, https://doi.org/10.15642/JIIS.2016.10.2.261-284.

${ }_{3}$ Clifford Geertz, The Interpretation Of Cultures (New York: Basic Books, Inc., Publisher, 1973). Clifford Geertz, The Religion OfJava (London: The University Of Chicago Press, 1976).

${ }_{4}^{4}$ Piotr Sztompka, Sociology Of Social Change (Cambridge USA: Oxford UK, 1993$), 3$.

5 Alvin Toffler, The Third Wave (New York: William Morrow and Company, INC, 1980). Aslan, "Peran Pola Asuh Orangtua di Era Digital," Jurnal Studi Insania 7, no. 1 (2019): 20-34.

6 Mujiburrahman, Agama, Media Dan Imajinasi: Pandangan Sufisme Dan Imu Sosial Kontemporer, Cetakan 2 (Banjarmasin: Antasari Press, 2015). Mujiburrahman, Agama Generasi Elektronik, Cetakan Pertama (Yogyakarta: Pustaka Pelajar, 2017).

7 Muhammad Luthfi Abdullah dan Akhmad Syahri, "Model of Religious Culture Education and Humanity," Nadwa 12, no. 2 (7 Januari 2019): 331-44, https://doi.org/10.21580/nw.2018.12.2.2756; M. Amin Abdullah, "Religion, Science, and Culture: An Integrated, Interconnected Paradigm of Science," Al-Jami'ab: Journal of Islamic Studies 52, no. 1 (8 Juni 2014): 175-203, https://doi.org/10.14421/ajis.2014.521.175-203.

8 Alvin Lee Bertrand, Social Organization;: A General Systems and Role Theory Perspective (F. A. Davis Co, 1971).

9 Aslan, "Nilai-Nilai Kearifan Lokal Dalam Budaya Pantang Larang Suku Melayu Sambas" 16, no. 1 (2017): 35-44. Aslan, "Pergeseran Nilai Di Masyarakat Perbatasan (Studi tentang Pendidikan dan Perubahan Sosial di Desa Temajuk Kalimantan Barat)," Disertasi, 2019, https://idr.uin-antasari.ac.id/10997/. Aslan dan Hifza, "The Community Of Temajuk Border Education Values Paradigm On The School," International Journal of Humanities,
} 
influencing people in society. In Islam, values that can create harmony in society are in accordance with Islamic teachings, which are guided by the Qur'an, Hadith, Ijmak and ijtihat.

Al-Qur'an contains values that can be used as guidelines for humans, especially specifically to the Islamic Ummah who have faith in both commands and prohibitions, consisting of moral ideas, laws, commands and prohibitions that refer to justified and forbidden things, promises (wa'ad) will heaven for the believers and threat (wa'id) hell for the wrongdoers. ${ }^{10}$ It also contains reports on various prophets and their former people, expressions, metaphors and warnings. In other words, the Koran teaches many positive values and forbids negative values with examples contained in the verses of the Koran, so that the writer feels interested to investigate further about socio-cultural education in the perspective of the Koran $a^{11}$.

Social education is education that is carried out by learning so that it becomes a positive value in itself and influences behavior. ${ }^{12}$ This behavior is inseparable from the relationship with the community through interaction. ${ }^{13}$ Humans as social beings means humans live in a container for the association of life where individuals interact with each other and interact socially and the interaction is inseparable from the culture in society. Thus, sociocultural education in the perspective of the Koran is every behavior that experiences development along with technological developments, but the behavior is still monotonous without experiencing development so that education is to awaken humans to behave that is not in accordance with the values Islam.

\section{METHOD AND MATERIALS}

This research method used literature review. The primary literature of this study was related to thematic interpretations. Thematic interpretation is a method of interpretation by gathering verses of the Koran that have a single goal that is incorporated in any theme and arrange them based on the passage of the verse, then explain, comment. The verse is studied thematically by looking at all its aspects, weighing it with the right scales of knowledge, discussing the nature of the theme, so that the target is easily known, fully mastered, so that he can understand the slightest things. In connection with the theme of socio-cultural

Religion and Social Science 4, no. 1 (2020): 13-20. Aslan, Agus Setiawan, dan Hifza, "Peran Pendidikan dalam Merubah Karakter Masyarakat Dampak Akulturasi Budaya di Temajuk," FENOMENA: Jurnal Penelitian 11, no. 1 (2019): 11-30, https://doi.org/10.21093/fj.v11i1.1403.

${ }^{10}$ Mahmud Ayub, al-Qur'an dan Para Penafsirnya (Jakarta: Pustaka Firdaus, 1992), 28.

11 Ali Sharaf Al-Musawi, Salim Al Akhzami, dan Abdullah Al Hinai, "The Omani Distance Learning Program to Teach the Holy Quran: Analytical Descriptive Study," TARBIY A: Journal of Education in Muslim Society 6, no. 1 (29 Desember 2019): 1-9, https://doi.org/10.15408/tjems.v6i1.11182; Afiful Ikhwan, "Leadership in Islamic Education: Study of Thematic Al-Qur'an and Al-Hadist," ULUL ALBAB Jurnal Studi Islam 17, no. 1 (25 Mei 2016): 31-46, https://doi.org/10.18860/ua.v17i1.3253.

12 Munandir, Ensiklopedia Pendidikan (Malang: UM Press, 2001), 229.

13 Alwi Hasan, dkk, Kamus Besar Bahasa Indonesia (Jakarta: Departemen Pendidikan Nasional Balai Pustaka, 2005). J. Dwi Narwoko dan Bagong Suyanto, Sosiologi Teks Pengantar dan Terapan (Jakarta: Kencana Prenada Media Group, 2005). Damsar, Pengantar Sosiologi Pendidikan (Jakarta: Kencana, 2011). 
education using the method of At Tafsir al Mawdhu'iy li Surah Qur'aniyyah namely the theme raised is the conclusion of discussion on the concepts of the Qur'an. ${ }^{14}$

Then, the terminalogical analysis of social and culture in Arabic is known as qaumun, syu'uban qabaila, ummatun and ahlul Qura. Qaumun means standing or staying or maintaining something. ${ }^{15}$ The basic word consists of the letters "qaf, waw, and mim". The phrase that uses qawama and its derivation repeats 224 times. From 224 times the qawama expression there are only 2 verses that are relevant to the discussion namely Q.S. Ar Ra'd verse 11, and Q.S Al Maidah verse 8. In QS. Ar Ra'ad 11 with the expression qaumin which means qaum, Q. Surah Annisa verse 34 qawwamun expression which means the leader and Q.S Al Maidah verse 8 with the phrase Qawamin which means Qaum. The word syu'uban means tribe. ${ }^{16}$ In the Qur'an, the word syu'uban has 2 repetitions. The relevant phrase is contained in Q.S Al Hujurat 13 which means nation. While the word qabaila comes from the words qaf, ba and lam. Qabaila means before, behind, stating the time / age, almanzilah, or order, arrangement. ${ }^{17}$

In the Qur'an the word qabala and its derivation occur 41 times and from two repetitions, only 1 is relevant, namely Q.S. Al Hujrat 13 with the expression qabail which means tribal. Another social word contained in the Qur'an is ummatun. The word ummatun is repeated in the Koran, for example in QS.Ar Ra'ad verse 11, QS. Al A'raf verse 34, Q.S Ali Imran verse 110 and verse 104. The word of the people in the Qur'an is also Ahlul Qura. In the Qur'an the Ahlul Qura is at least contained in S. Al A'raf verses 96.97 and 98. Cultures that are equivalent in Arabic are called Shana'a, kasaba, and 'amalu. Shana'a means doing something. ${ }^{18}$ The word shana'a and its derivation in the Qur'an are found in 18 verses. (Faturraji, Lithalabi Ayil al Qur'an, p.260) Of the 18 verses, those that are relevant to the chosen theme are 12 verses that are relevant to the theme. These verses are: Q.S Hud verses 15-16, Q.S Thaha 69, Q.S Hud 38, QS. Annahal: 112, QS. Annur verse 30, QS. Al Fatir: 8, QS. Al Angkabut 45, QS.Hud, 37, QS. Al Mu'minun 27. Kasaba in Arabic means the word kasaba and its derivation in the Qur'an contained in 52 verses. ${ }^{19}$ Of these verses will be presented in this interpretation, namely: QS. At Tur 21, Al Baqarah verses 81, and 134, Ali Imran 25, and al An'am 70. While 'Amila in Arabic means to make. The word 'amila is found in 5 verses. ${ }^{20}$ From these verses that will be interpreted according to themes such as Q.S. Al Baqarah 25, Q.S Al Qasas 84, Al Furqan verse 23, QS. Taghabun 7, QS. Arrum 41.

14 Abdullah Karim, Metodologi Tafsir Al Qur'an (Banjarmasin: Comdesh Kalimantan, 2011), 127-128. M. Yunan Yusuf, "Metode Penafsiran al-Qur'an: Tinjauan atas Penafsiran Al-Qur'an secara Tematik," Syamil 2, no. 1 (2014): 57-67.

${ }^{15}$ Ar Raqib Al Ispihaniy, Mu’jam Mufradat Alfą̧ al-Qur'an (Beirut Libanon: Dar al Fiqr, t.t.), 431.

16 Ispihaniy, 268.

17 Ispihaniy, 405.

18 Ispihaniy, 294.

${ }^{19}$ Faturraji, Lithalabi Ayil al Qur'an, h.387

${ }^{20}$ Faturraji, Lithalabi Ayil al Qur'an, h.317 


\section{SOCIAL CULTURE EDUCATION ACCORDANCE TO THE QURAN}

The theme of the discussion in this paper consists of two parts. First, social education according to the Qur'an. Second, cultural education according to the Qur'an. Social Education according to the Qur'an. Human nature is a creature that lives in society. The formation of a society requires individuals who want to obey the rules of social life. Education as an institution tasked with educating its members is still easy with various activities so that later they can become citizens. The Qur'an emphasizes several principles that must be considered in implementing social education. The social education category in the Koran consists of;

\section{Humans are social beings who have the same degree}

Surat al Hujurat verse 13, explained that humans are social beings who have the same degree. This verse came down when the conquest of the city of Mecca which Bilak ascended the Kaaba and echoed the call to prayer. The contradiction of Bilal who is considered a black servant and not worthy of the call to prayer, so this verse comes down. ${ }^{21}$ The content contained in the above verse confirms that although humans were created consisting of nations and tribes, they should know each other and do not feel that each is superior to the nation that another, because according to God there is no difference, except taqwa. Therefore, one of the contents of education that must be conveyed to students is the view that Islam teaches equality, not to discriminate both on the basis of economic status, social status, color, race or race and others.

Education must be directed at the formation of a mental attitude that wants to change for progress.

In Al-Qur'an S.Ar Ra'ad verse 11, Quraisy Syihab explains that this verse talks about social change. the use of the word qaum refers to society as a whole regardless of ethnicity, language and religion. Change consists of two parts, namely God and humans. Changes that occur in humans depend on their own will and hard work, such as in terms of wealth, poverty, health, disease, and glory. ${ }^{22}$

Signs of instilling an attitude to be careful so as not to be affected by the threat of God that a community will be destroyed if disobedient to God

This is an education in the form of a warning so that humans become more warning with all the commands of God. Regarding this signal, the Word of God in Surah Al A'raf: 34, implies a time of community collapse and destruction. Muslims must learn from the previous people who were destroyed by Allah due to disobedience to Allah Ummah Noah, qaum Lut, qaum Ad and qaum Thamud contained in Surah Ash Shafat verse 136, (ceritra the destruction of the Loth) S. Al 'Araf 135 (the story of the destruction of Fir'awn and his followers) and others. ${ }^{23}$

${ }^{21}$ Abdullah bin Muhammad bin Abdurrahman bin Ishaq Alu Syaikh, Lubaabut Tafsir Min Ibni Katsir, Terj. Abdul Ghoffar, 5 ed. (Bogor: Cetakan Imam Syafi'i, 2007), 517.

${ }_{22}$ M. Quraish Shihab, Tafsir Al-Mishbah: Pesan, Kesan dan Keserasian Al-Qur'an (Jakarta: Lentera Hati, 2002), 569.

23 Shihab, 85. 
Instill an attitude of willingness to invite others to do ma'ruf and prevent people from doing evil.

Al-Qur'an S. Ali Imran verse 110, explains that a good people are people who order to the ma'ruf and prevent munkar. Talking about preventing the evil is told in the Koran, for example in surah al-Maidah verses $78-79 .^{24}$

The implementation of education must be aimed at the purpose of educating citizens to become people of faith and piety

QS. Al A'raf verse 96, which is interpreted by the Quraish Shihab that people who are ungodly to Allah, will be tortured on them. This verse is understood also as a sign of Allah to provide abundance of blessing for the inhabitants of the land of the faithful and devoted. ${ }^{25}$ And vice versa Allah also inherit for the people who are sinful and do not want to repent, the torture and punishment are also very heavy. So there are two sides which require that every Ummah must be obedient and responsible both as social beings and creatures of God.

On the basis of the meaning of the Qur'anic verses and the hadith above, both the purpose and content of learning must be designed so as to be able to educate Muslims to become people of faith and piety. Material relating to aqidah, worship, shari'ah and muamalah Islam must be provided in various educational institutions both informal, formal, and non-formal as early as possible with sufficient proportions according to the demands of educational objectives, namely to form a faithful and pious human being besides being part of a community group a matter of caring about one another.

\section{Instill an attitude of justice in society}

Social justice is a strict command in the Qur'an Surah Al Maidah verse 8. In the Qur'an the commandment of justice has been repeated 28 times (Shihab, 1998, p.114) This shows that the order to uphold justice is very important in Islam. The above verse means social justice, meaning that justice must be given to the people in the form of not acting unjustly to other people even though the people are hated, even to infidels who do not fight the Muslims Allah does not forbid to do good and be just as there is the Qur'an 'an S.Al Mumtahanah verse 8). That is among others the importance of the science of social justice in Muslim societies.

${ }^{24}$ Maulana Zakaria Al-Kandahlawi, Himpunan Fadilah Amal., Terj. A. Abdurrahman Abmad, dke (Yogyakarta: Ash Shaf, 2006), 633.

${ }^{25}$ Shihab, Tafsir Al-Mishbah: Pesan, Kesan dan Keserasian Al-Qur'an, 181-82. 


\section{CULTURAL EDUCATION ACCORDING TO THE GUIDANCE OF THE KORAN}

Allah created mankind equipped with reason and mind power. With reason, humans create something in order to meet their needs. The work, taste and creativity to produce culture by having three forms. The first form as ideas, ideas, values, norms and regulations. The second form of human action and the third form is the result of human work. ${ }^{26}$ The verses related to socio-cultural education, including;

\section{Education aims to instill moral values and do good deeds}

This type of education is found in the Qur'an as Surah Al-'Asr verses 1-3. This verse describes the loss of people who do not believe and do good deeds. ${ }^{27}$ The educational values of this category are carried out sincerely and in accordance with Islamic rules. With good values and social skills among people, then here Islam clearly has values that are truly needed by the Islamic Ummah and universally acceptable common sense.

\section{Prohibition of creating something that can cause polytheism}

One of the apostolic tasks in the world sent is to free people from shirking God. Many verses of the Qur'an which forbid doing polytheism are found in the Qur'an. Among them is Surah Al Baqarah verse 22, Surah Ibrahim verse 30, Luqman verse 30. The verses of the Qur'an above explicitly forbid Muslims from practicing polytheism. Therefore educational institutions must be able to instill understanding of forms of polytheism in order to avoid it. Along with the development of society today, especially in Indonesia began to emerge polytheistic cultures such as ascetic mountain to get pesugihan, traditional ceremony of sea alms, cleaning the kris, maintaining amulets and staking a fate with the help of jinn and superstition. Although this is indeed present in society, Islam strictly forbids this because it believes that this will lead mankind to the path of polytheism and the loss of the world and the hereafter. ${ }^{28}$

\section{Counseling education in Islam as instilling understanding that personal responsibility is good and bad what is done.}

Islam confirms that a person will receive the consequences / replies from each of what is done contained in the Qur'an S. At Tur verse 21. Ibn Kathir in interpreting this verse with regard to Ibn Abbas states that they are the descendants of the believers who died who brought his faith. After Allah Almighty states about His superiority which will raise the offspring of believers to the degree of their faithful ancestors, even though their charity is not equal, then Allah shows His justice that one will not be held accountable for the sins of others. Allah says: Every human being is bound by what he does. Namely that he will be held accountable for his actions, no human being will bear the burden of the sins

26 Koentjaraningrat, Pengantar Ilmu Antropologi (Jakarta: Rineka Cipta, 2014). Alfani Daud, Islam dan Masyarakat Banjar: Deskeripsi dan Analisa Kebudayaan Banjar (Jakarta: PT. Raja Grafindo Persada, 1997). M. Suriansyah Ideham dkk., Urang Banjar \& Kebudayaannya., (Ed) M. Suriansyah Ideham, H. Sjarifuddin, M. Zainal Arifin Anis, Wajidi, Cet-2 (Yogyakarta: Ombak, 2015).

${ }^{27}$ Fachruddin HS, Terjemahan Hadis Shabih Muslim, 1 ed. (Jakarta: Bulan Bintang, 1981), 22.

${ }_{28}$ Adian Husaini, Pendidikan Islam Membentuk Manusia Berkarakter dan Beradab (Indonesia: Komunitas Nuun, 2011). 
of others he did not do. ${ }^{29}$ This explanation means that humans as social beings have personal responsibilities. Good and bad that he did will get rewarded in accordance with the charity what was done. So if the crime is done together in the community then the crime response is limited to those who participate in carrying out the evil deeds, not the responsibility of the whole community. Likewise, the kindness done by members of the community, although it is done together, the reward in the hereafter is only for each person who does it, as in the word QS. Al Baqarah verse 141.

\section{Prohibition against creating something that can damage nature}

Nature was created by God to meet human needs. God has created a balanced natural system. Therefore God asserts that nature can be damaged if humans are wrong in managing it. Associated with Allah's statement that the destruction of nature is the result of human activity has been revealed by God in QS. Arrum verse 41 and QS. Al 'Araf verse 56. Furthermore, when examined more deeply, the universe is created everything but Allah has a goal to be achieved. therefore, the universe is actually not just the sky and the whole earth, but it includes everything in it, both at sea and on land, both abstract and concrete or that cannot be seen by our senses. Where the universe is divided into two realms, namely the natural light and the unseen or unseen realm witnessed by our five senses.

Quraish Shihab interprets this verse about the prohibition to damage the earth. ${ }^{30}$ Damage on earth, the environment can take the form of soil damage due to erosion, or poisoning, water damage due to pollution of poisons or other harmful substances, as well as air damage due to the amount of toxic gases from factory wastes or motor vehicles. This damage is all according to God's law, "It has been seen that damage on land and in the sea is caused by the actions of human hands, so that Allah feels to them part of (the consequences) their actions, so that they return (to the right path)." (Surah Al-Rûm [30]: 41).

\section{May get involved in managing the country}

There are many stories in the Qur'an about the messenger who acts as the ruler of the state. There are those who act as kings, or other state officials. One of them is the Prophet Joseph who acts as the State treasurer found in Surah Yusuf verse 55. The Word of God, among others, Said Joseph: "Make me the treasurer of the country (Egypt); in fact I am a person who is good at maintaining, more knowledgeable" next interpretation of the Qur'an Yusuf Verse 55 55. Joseph said to the king, "Give me the duty of guarding the warehouses of wealth and food in the land of Egypt. Because I am a trusted guard, and have good knowledge and insight about my duties and authority."

\section{Education must teach the skills to make the tools of human life.}

In living the life of both humans as individuals and humans as members of society requires a variety of tools/ tools of life. The tools of life such as shelter, transportation, communication equipment, medical devices, jewelry and others. In connection with the mighty life, then the Qur'an has included them in S.Hud verse 37. "And make the ship with our supervision and care, and with our revelations that teach you how to make it. And do not talk to Me to ask for the suspension of time for those who wrong themselves by being

\footnotetext{
29 Syaikh, Lubaabut Tafsir Min Ibni Katsir, Terj. Abdul Ghoffar.

${ }^{30}$ Shihab, Tafsir Al-Mishbab: Pesan, Kesan dan Keserasian Al-Qur'an, 123.
} 
infidels. Because they will surely be drowned with floods as a punishment for the hardness of their hearts in defending unbelief.

\section{CONCLUSION}

The thematic study of socio-cultural education is contained in the Qur'an, we can draw conclusions including; First, humans are social beings who have the same degree (Q.S al Hujurat: 13). Secondly, education must be directed towards the formation of a mental attitude that wants to change for progress (Q.S.Al Qur'an S.Ar Ra'd: 11). Third, inculcation of caution so as not to be affected by the threat of God that a society will be destroyed if disobedient to God. (Surah Al Araf: 34). Fourth, inculcating attitude to invite others to do ma'ruf and prevent people from doing evil (Qur'an S. Ali Imran: 110). Fifth, the implementation of education must be aimed at the purpose of educating citizens to become people of faith and piety (QS. Al A'raf: 96). Sixth, Instilling the attitude of justice in society (QS. Al Maidah: 8). Seventh, education must be aimed at efforts to instill values so that children want to do good deeds (Qur'an S. Al-'Asr: 3). Eighth, do not create something that can cause polytheism (Q.S.Al Baqarah: 22.). Ninth, education is intended to instill an understanding that personal responsibility is good and bad what is done (QS. At Tour: 21). Tenth, do not create something that can damage nature (QS.Arrum: 41). Eleventh, may be involved in managing the country (Surah Yusuf: 55). Twelfth, education must teach humans to make the tools necessary for life (QS.Hud: 37).

\section{REFERENCES}

Abdullah, M. Amin. "Religion, Science, and Culture: An Integrated, Interconnected Paradigm of Science." Al-Jami'ah: Journal of Islamic Studies 52, no. 1 (8 Juni 2014): 175-203. https://doi.org/10.14421/ajis.2014.521.175-203.

Abdullah, Muhammad Luthfi, dan Akhmad Syahri. "Model of Religious Culture Education and Humanity." Nadwa 12, no. 2 (7 Januari 2019): 331-44. https://doi.org/10.21580/nw.2018.12.2.2756.

Al-Kandahlawi, Maulana Zakaria. Himpunan Fadilab Amal., Terj. A. Abdurrabman Abmad, dkk. Yogyakarta: Ash Shaf, 2006.

Al-Musawi, Ali Sharaf, Salim Al Akhzami, dan Abdullah Al Hinai. "The Omani Distance Learning Program to Teach the Holy Quran: Analytical Descriptive Study." TARBIY A: Journal of Education in Muslim Society 6, no. 1 (29 Desember 2019): 1-9. https://doi.org/10.15408/tjems.v6i1.11182.

Alwi Hasan, dkk. Kamus Besar Bahasa Indonesia. Jakarta: Departemen Pendidikan Nasional Balai Pustaka, 2005.

Aryanto, Aris, Bani Sudardi, Andrik Purwasito, dan Abdullah Wakit. "Social Criticism in the Text Scripture of Dharmasonya." Komunitas: International Journal of Indonesian Society and Culture 9, no. 1 (2017): 70-80.

Aslan. "Nilai-Nilai Kearifan Lokal Dalam Budaya Pantang Larang Suku Melayu Sambas” 16, no. 1 (2017): 35-44.

. "Peran Pola Asuh Orangtua di Era Digital.” Jurnal Studi Insania 7, no. 1 (2019): 2034. 
—. "Pergeseran Nilai Di Masyarakat Perbatasan (Studi tentang Pendidikan dan Perubahan Sosial di Desa Temajuk Kalimantan Barat).” Disertasi, 2019. https://idr.uin-antasari.ac.id/10997/.

Aslan, dan Hifza. "The Community Of Temajuk Border Education Values Paradigm On The School." International Journal of Humanities, Religion and Social Science 4, no. 1 (2020): 1320.

Aslan, Agus Setiawan, dan Hifza. "Peran Pendidikan dalam Merubah Karakter Masyarakat Dampak Akulturasi Budaya di Temajuk." FENOMENA: Jurnal Penelitian 11, no. 1 (2019): 11-30. https://doi.org/10.21093/ff.v11i1.1403.

Asrori, Achmad. "Contemporary Religious Education Model on the Challenge of Indonesian Multiculturalism." JOURNAL OF INDONESLAN ISLAM 10, no. 2 (1 Desember 2016): 261-84. https://doi.org/10.15642/JIIS.2016.10.2.261-284.

Ayub, Mahmud. al-Qur'an dan Para Penafsirnya. Jakarta: Pustaka Firdaus, 1992.

Bertrand, Alvin Lee. Social Organization;: A General Systems and Role Theory Perspective. F. A. Davis Co, 1971.

Damsar. Pengantar Sosiologi Pendidikan. Jakarta: Kencana, 2011.

Daud, Alfani. Islam dan Masyarakat Banjar: Deskripsi dan Analisa Kebudayaan Banjar. Jakarta: PT. Raja Grafindo Persada, 1997.

Fachruddin HS. Terjemahan Hadis Shabih Muslim. 1 ed. Jakarta: Bulan Bintang, 1981.

Geertz, Clifford. The Interpretation Of Cultures. New York: Basic Books, Inc., Publisher, 1973.

- The Religion OfJava. London: The University Of Chicago Press, 1976.

Husaini, Adian. Pendidikan Islam Membentuk Manusia Berkarakter dan Beradab. Indonesia: Komunitas Nuun, 2011.

Ideham, M. Suriansyah, Jurliani Djohansjah, Djantera Kawi, Sjarifuddin, Syamsiar Seman, Gazali Usman, Bachtiar Sandeta, dkk. Urang Banjar \& Kebudayaannya., (Ed) M. Suriansyah Ideham, H. Sjarifuddin, M. Zainal Arifin Anis, Wajidi. Cet-2. Yogyakarta: Ombak, 2015.

Ikhwan, Afiful. "Leadership in Islamic Education: Study of Thematic Al-Qur'an and AlHadist." ULUL ALBAB Jurnal Studi Islam 17, no. 1 (25 Mei 2016): 31-46. https://doi.org/10.18860/ua.v17i1.3253.

Ispihaniy, Ar Raqib Al. Mu'jam Mufradat Alfað̧h al-Qur'an. Beirut Libanon: Dar al Fiqr, t.t.

J. Dwi Narwoko dan Bagong Suyanto. Sosiologi Teks Pengantar dan Terapan. Jakarta: Kencana Prenada Media Group, 2005.

Karim, Abdullah. Metodologi Tafsir Al Qur'an. Banjarmasin: Comdesh Kalimantan, 2011.

Koentjaraningrat. Pengantar Ilmu Antropologi. Jakarta: Rineka Cipta, 2014.

Mujiburrahman. Agama Generasi Elektronik. Cetakan Pertama. Yogyakarta: Pustaka Pelajar, 2017.

. Agama, Media Dan Imajinasi: Pandangan Sufisme Dan Ilmu Sosial Kontemporer. Cetakan 2. Banjarmasin: Antasari Press, 2015.

Munandir. Ensiklopedia Pendidikan. Malang: UM Press, 2001.

Setiadi, Elly M., dan dkk. Ilmu Sosial dan Budaya Dasar. Jakarta: Kencana, 2008.

Shihab, M. Quraish. Tafsir Al-Mishbab: Pesan, Kesan dan Keserasian Al-Qur'an. Jakarta: Lentera Hati, 2002. 
Hilmi Mizani

Syaikh, Abdullah bin Muhammad bin Abdurrahman bin Ishaq Alu. Lubaabut Tafsir Min Ibni Katsir, Terj. Abdul Ghoffar. 5 ed. Bogor: Cetakan Imam Syafi'i, 2007.

Sztompka, Piotr. Sociology Of Social Change. Cambridge USA: Oxford UK, 1993.

Toffler, Alvin. The Third Wave. New York: William Morrow and Company, INC, 1980.

Yusuf, M. Yunan. "Metode Penafsiran al-Qur'an: Tinjauan atas Penafsiran Al-Qur'an secara Tematik." Syamil 2, no. 1 (2014): 57-67. 